Original Research Paper

\title{
The Effect of Diversification of Banking Products on the Relationship between Market Power and Financial Stability
}

\author{
Sami Mensi and Widede Labidi \\ Graduate College of Commerce of Tunis (ESCT), University of Manouba and ECSTRA Laboratory, Tunisia
}

Article history

Received: 30-04-2015

Revised: 26-05-2015

Accepted: 21-10-2015

Corresponding Author:

Widede Labidi

Graduate College of Commerce of Tunis (ESCT), University of Manouba and ECSTRA

Laboratory, Tunisia

Email: widede1988@hotmail.fr

\begin{abstract}
In the context of financial liberalization, increased competition has spurred financial institutions to develop new products and new activities in order to meet demand, market development and increased competitiveness. This has made the relationship between market structure and financial stability more complicated and its study through the channel of diversification remains an unexplored area. The purpose of this paper is to test the interaction between market power, diversification and financial (in) stability. To this end, we examine a sample of 18 countries in the MENA region and 157 commercial banks during the period 2000-2013. Supporting the "competition-instability" hypothesis, our results revealed that low market power banks in the MENA region are less robust and more unstable when they less or poorly diversify their activities. Moreover, financial instability in this sector may result from a fierce competition among banks born from the desire to distinguish themselves by offering various nontraditional products, for which banks lack the experience to control its risks.
\end{abstract}

Keywords: Market Power, Financial Stability, Competition,

\section{Introduction}

Many consider competition in the banking sector as a factor behind the efficient production of financial services, quality of financial products and degree of financial innovation Claessens and Laeven (2004; Amidu and Wolfe, 2013). Moreover, other authors like Berger et al. (2009) assume that competition influences banking stability. The question of why competition should have an effect on the soundness of the banking system remains a matter which is not fully explored.

For almost two decades of promotion efforts for the entry of foreign banks, consolidation and other structural reforms, competition has increased forcing credit institutions to diversify their revenue sources to maintain their future cash flows and franchise values. Suddenly, there was a surge of non-interest-based activities, such as securitization, credit securitization, derivatives securitization and derivatives...

With the current wave of financial liberalization, financial institutions were encouraged to develop new products in order to meet demand because of a development of the market, increase in competitiveness, expansion of economies of scale and the promotion of globalization and diversification. In this regard, Amidu and Wolfe (2013) believe that competition forces banks to adopt diversification strategies, which would affect banking risk. In addition to changes in competition that pushed banks to diversify their activities, there is what is known as the hedging strategy (Froot and Stein, 1998), a mechanism to improve profitability and operational efficiency of banks (Landskroner et al., 2005) and to strengthen the function of banks as delegated monitors (Baele et al., 2007).

Despite these arguments in favor of diversification, the results of its impact on banking insolvency risk are mixed. Some studies show that there is no benefit to diversification such as those of Stiroh (2004; Hirtle and Stiroh, 2007; Mercieca et al., 2007). In contrast, other studies like those of (Landskroner et al., 2005; Baele et al., 2007; Sanya Wolfe, 2011) found that diversification plays a key role in stimulating banking stability. Despite the remarkable momentum of income diversification, the relevant literature is scarce and undeveloped.

Although the above arguments present the theoretical and empirical foundations of the relationship between 
competition, diversification and stability. To our knowledge, this paper is the first to investigate the role of diversification in relation to market power and financial stability using a panel data of a set of banks in the MENA region. In fact, this type of investigation is often conducted in the United State and European countries, not in emerging or developing countries. Banks in developed countries had been operating in an environment of financial repression in the 80 s and since then banks have suffered significant regulatory and structural changes. In addition, this study is important because income diversification, through interest and non-interest income revenues, may have a variable impact, direct or indirect, on banking stability through banks' market power.

The relationship between market power, income diversification through other than interest-based activities remains unexplored and yet ambiguous. Our study examines the trilateral relationship between market power, bank income diversification and banking stability after controlling for countries- and bank-specific factors. The objective of this study is to focus on whether the revenue diversification interacts with market power and produces stabilizing or destabilizing effects on the banking entity. We have to test the following hypotheses H0: The interaction between banking revenue diversification and market power produces stabilizing effect, versus H1: The interaction between banking revenue diversification and market power produces destabilizing effect. We argue that the study of such an impact is important because market power leads banks in one way or another to identify revenue growth opportunities from interest, commissions and capital gain on financial securities. Market power provides greater ability to negotiate new contracts under new conditions.

This paper is organized as follows: Section 2 is devoted to a review of the theoretical and empirical literature on the relationship between banking market power, diversification and financial stability. Section 3 presents the models used, identifies key variables and explains the various measures adopted. Section 4 presents the methodology, the sample, study period and databases. Section 5 presents and discusses the results and finally section 6 concludes.

\section{The Literature Review}

Deregulation and increased competition have led banks to diversify their income sources by seeking to operate in new activities such as underwriting and trading securities, investments and other activities that generate income other than interest. Accordingly, a body of research has focused attention on the impact of banking diversification in developed countries. Regarding the United States (US) banking sector, most studies show that increased participation in activities other than interest-collecting activities increases risk (DeYoung and Roland, 2001; Stiroh, 2004a; 2004b; 2005; Stiroh, 2006; Stiroh and Rumble, 2006; DeYoung and Torna, 2013). Like the US studies, European banks' adoption of activities other than interest-based also increases banking risk (Lepetit et al., 2008a; Mercieca et al., 2007; Chiorazzo et al., 2008; De Jonghe, 2010). In fact, several studies studied the relationship between income-raising diversification other than activities with interest and interest margins (Lepetit et al., 2008a), technological advancement (DeYoung and Rice 2004; Carba-Valverde and RodriguezFernandez, 2007), credit risk (Lepetit et al., 2008) and efficiency (Lozano-Vivas and Pasiouras, 2010).

While a significant number of studies examined the effect of income diversification on banking performance in developed countries, relatively few papers address this issue on banks in developing and emerging countries. However, the implications of these earlier studies may not be applicable to emerging/developing countries. Indeed, differences in institutional and regulatory environments and the specific characteristics of banking markets in less developed/emerging countries and developed countries may justify different effects of changes in the income structure of the bank (Nguyen et al., 2012). In addition, the authors emphasize the benefits of income diversification in emerging markets and examine the relationship between banking market power and income diversification. Their study focused on whether this diversification interacts with market power and produces stabilizing or destabilizing effects on the banking entity. The authors showed that South Asian banks characterized by high market power seek traditional interest-based activities. However, these banks become more stable when diversifying their activities between interest-based and non-interestbased income activities.

Amidu and Wolfe (2013) examined how competition affects diversification and stability on a sample of 55 emerging and developing countries. The authors put an emphasis on the relationship "competition -stability" by examining the complex relationship between three key variables: The bank's market power degree, diversification and banking stability. The basic finding is that banking competition leads to stability by means of diversification between interest-generating and interest non-generating activities. Amidu and Wolfe (2013) support the idea that diversification is a channel through which competition affects banking failure risk in emerging countries.

The study of Chien-Chiang et al. (2014) contributes to the literature by examining the impact of income diversification on the performance of a sample of banks from 29 countries in Pacific Asia through a wide range 
of financial reforms. This study is the first to examine whether financial structures influence the effect of diversification on the performance of each bank. Another study on diversification and banking performance conducted by Meslier et al. (2014) examined the impact of bank income diversification on the performance of banks in emerging economies, using a unique data set with detailed information on non-interest-based activities. The results show that, contrary to studies on Western economies, opting for non-interest-activities activities increases profits of banks and risk-adjusted profits.

The review of the literature shows that the relationship between market power and income diversification has been recently explored yet it is still ambiguous. In fact, various studies have investigated the impact of market power on various aspects of banking activities, such as interest margin (Maudos and De-Gevara, 2004), financial stability (Jimnez and Saurina, 2004; Agoraki et al., 2011), banking efficiency (Delis and Tsiones, 2009; Ariss, 2010) and banking regulation (Beck et al., 2006; Fonseca and González, 2010; Carba-Valverde and Fernandez, 2007) highlighted the relationship between market power and diversification of banking activities. The study explains how banking market power increases when the bank diversifies its investment in non-traditional banking activities. However, this study is limited to 5 developed European countries. Other studies, like that of Nguyen et al. (2012) support the idea that the bank can gain market power through nontraditional banking activities when it cut its interest margins or the interest rate of traditional credit products. It turns out that it is possible that market power and income diversification are simultaneously determined.

\section{The Methodology}

\section{Data}

\section{Sample and Period}

Our database is constructed from several sources. Data specific to each bank are obtained from the Bankscope database. Macroeconomic data are obtained from the World Development Indicators database of the World Bank and Financial Statistics of the International Monetary Fund. Our sample consists of 18 countries in the MENA region, with 157 commercial banks as follows Algeria (10), Bahrain (9), Egypt (23), Iran (8) Iraq (1), Israel (6), Jordan (10), Kuwait (5), Lebanon (18) Libya (4), Morocco (9), Oman (5), Qatar (6), Saudi Arabia (9), Syria (1), Tunisia (14) United Arab Emirates (15), Yemen (4). Moreover, the selected time range covers 14 years from 2000 to 2013.

\section{Data}

The purpose of our study was to focus our interest on commercial banks that can diversify these products within the business assigned to them. We excluded banking institutions such as investment banks, savings banks, cooperative banks. Other non-banking financial intermediaries such as insurance companies and mortgage agencies are also excluded because of their regulatory requirements which are different from those of commercial banks. The sample is also filtered by excluding banks with less than three consecutive annual observations or where the main variables are not available.

The data concerning the variables measuring financial stability are fully reproduced from ChienChiang et al. (2014); Amidu and Wolfe (2013); Ariss, (2010); Soedarmono et al. (2011; 2013); Boyd et al. (2006) and Uhde and Heimeshoff (2009). They measured $\mathrm{Z}$-score as an index to evaluate the soundness of the banking market. These components, as mentioned by Ariss (2010) and Uhde and Heimeshoff (2009), are particularly interesting in that they use Return On Assets (ROA) as a measure of banking profitability and SDROA as an approximate measure of profitability volatility or banking revenues.

Therefore, in order to estimate the relationship between market power and financial stability, it is necessary to add a variable measuring degree of market power. This variable describes the institutional environment in which banks operate. There are several measures of degree of market power used in the literature i.e., H-statistic of Panzar and Ross (1987), the model of Bresnahan (1982) and Lau (1982) and the Lerner index. Regarding H-statistic, we should make sure that the H-statistic measures degree of competition as it has been used in various studies (Schaeck et al., 2009). It is, however, criticized by Goddard and Wilson (2006) who assume that a market in which the statistics are used, is an equilibrium market which is not the case in reality. In this study, we use the Lerner index as a variable measuring degree of market power. The variable (Div) is the proxy of income diversification measured by deriving the Herfindahl-Hirschman Index (HHI) for each bank. This measure takes into account diversification between the main activities like in the study of Trujillo-Ponce (2013), Amidu and Wolfe (2013), Chien-Chiang et al. (2014). The control variables that are introduced in the model include variables related to the macroeconomic environment and variables specific to each bank. This choice of variables is mainly inspired by Schaeck et al. (2009), Maudos and Guevara (2007) and Beck et al. (2006). On the one hand, to control the impact of macroeconomic development on the banking system of a country, we choose inflation rate (INF) and GDP growth rate (TCPIB). According to Cihak and Schaeck (2007) and Maudos and De Guevara (2007), these variables greatly affect the quality of bank assets and bank capitalization. These two variables are specific to each country. 
Furthermore, two specific variables to each bank were introduced reflecting the behavior of risk-taking among banks consistent with the principle of " too Big to Fail" (Mishkin, 2006). The variables are bank size (SIZE) and loan growth rate (TCP). Size of each bank is approximated by the logarithmic mean of the total assets (Maudos and De Guevara, 2007). In addition, it incorporates the Loan-To-Deposit Ratio (LDR) that tells us about the level of bank liquidity that can influence the banking failure probability and the Loan-Loss Reserve Ratio (LLR), which measures the credit risk that is equal to the reserves for loan losses/total loans.

\section{Operationalizing Key Variables}

\section{Market Power}

We chose the Lerner index as a measure of market power degree. Several studies have used to this index like those of De Guevara et al. (2004); Maudos and De Guevara (2007), Berger et al. (2009), Ariss (2010) and Soedarmono et al. $(2011 ; 2013)$.

Our motivation behind choosing such an index is because of its simplicity in terms of its empirical application and whose formula is as follows:

$$
\text { Lerner }_{i, t}=\left(\text { Price }_{i, t}-\text { Marginal Cost } t_{i, t}\right) / \text { Price }_{i, t}
$$

With $\mathrm{P}$ the average price or the price of the bank's outputs as measured by net charge/total assets ratio, $\mathrm{Cm}$ represents marginal cost estimated by a translog cost function (De Guevara et al., 2005; Sallami and Chaffai, 2011):

$$
\begin{aligned}
& \ln T C_{i}=\alpha_{0}+\alpha_{1} \ln T A_{i}+\frac{1}{2} \alpha_{2}\left(\ln T A_{i}\right)^{2}+\sum_{\mathrm{j}=1}^{3} \beta_{j} \ln w_{j i}+ \\
& \frac{1}{2} \sum_{\mathrm{j}=1}^{3} \sum_{\mathrm{k}=1}^{3} \beta_{\mathrm{jk}} \ln w_{j i} \ln w_{k i}+\frac{1}{2} \sum_{\mathrm{j}=1}^{3} \gamma_{\mathrm{j}} \ln T A_{i} \ln w_{j i}+\mu_{1} T r e n d+\mu_{2} \frac{1}{2} \text { Trend }^{2}+ \\
& +\mu_{3} \text { Trend } \ln T A_{i}+\sum_{j=1}^{3} \lambda_{j} \text { Trend } \ln w_{j i}+\ln u_{i}
\end{aligned}
$$

Total Cost (TC) depends on the price of the three inputs (labor, physical capital and deposits) and is approximated by total expenditures. In addition, Total Assets (TA), which represents the bank's production volume (the amount of outputs), depends on the technical changes represented by the variable (Trend), because total assets are aggregated to the amount of expected outputs of each bank $\mathrm{q}_{\mathrm{it}}$. Price of labor $\left(\mathrm{w}_{1 \mathrm{it}}\right)$ is measured by the ratio (staff/total assets). The price of capital $\left(\mathrm{w}_{2 \mathrm{it}}\right)$ is the ratio (fixed assets/total assets). Price of capital $\left(\mathrm{w}_{3 \mathrm{it}}\right)$ is the ratio (interest fees/total deposits).

The marginal cost calculated from the above equation is as follows:

$$
M C_{i}=\frac{T C}{T A}\left(\alpha_{1}+\alpha_{2} \ln T A_{i}+\frac{1}{2} \sum_{j=1}^{2} \gamma_{j} \ln w_{j i}+\mu_{2} \text { Trend }\right)
$$

The Lerner index is interpreted as follows: An index that exhibits a high value implies a greater power in pricing and the lowest competitive conditions of the market.

\section{Measurement of Diversification}

Income diversification is measured by the construction of the Herfindahl-Hirschman Index (HHI) for each bank. This measure takes into account diversification between the core activities. Div is the proxy for income diversification. This study differs from other studies in the literature which focused exclusively on asset diversification or income diversification. Like Trujillo-Ponce (2013), Amidu and Wolfe (2013) and Chien-Chiang et al. (2014) who used a Herfindahl-Hirschman index adjusted for different types of revenue to measure income diversification, the Div variable is as follows:

$$
\text { Div }=1-\left[\begin{array}{l}
(\text { INT } / \text { TOR })^{2}+(C O M / T O R)^{2}+ \\
(T R A D / T O R)^{2}+(O T H / T O R)^{2}
\end{array}\right]
$$

With (INT) is gross interest income, (COM) Commission net income (TRAD) net trading income and $(\mathrm{OTH})$ all other net incomes. We calculate the Total Operating Revenue (TOR) as the denominator to avoid potential distortion of the use of total assets or interestbased income. The Div index takes values between zero if the bank is fully specialized in a business area and 0.75 if the bank generates a mixture of incomes totally balanced on the four sectors.

\section{Financial Stability}

Like in Chien-Chiang et al. (2014), Amidu and Wolfe (2013), Soedarmono et al. (2011; 2013), Nguyen et al. (2012), Ariss (2010), Agoraki et al. (2011) and others, we try to find an adequate measure of financial (in) stability in practice. To this end, we choose Z-score as an index that measures degree of stability of banks. In the same indicator, we incorporate three elements, namely bank capitalization, bank earnings volatility and insolvency risk.

Indeed, bank capitalization is measured by the equity to total assets (EQ/TA) ratio. Moreover, to measure bank earnings volatility, which reflects risk-taking strategies, we use the standard deviation of ROA and ROE, noted respectively SDROA and SDROE.

In fact, this measure of bank earnings volatility represents an enhancement of the degree of risk-taking of banks. Furthermore, to assess insolvency risk we use two measures of Z-score. One is based on the ROA and the other is based on ROE and presents Z-score ROA and Z-score ROE respectively. The following formulas illustrate these steps: 


$$
Z_{R O A}=(R O A A+E Q / T A) / S D_{R O A}
$$

With ROA is return on average assets, ROE is return on average equity.

$$
Z_{R O E}=(R O A E+1) / S D_{R O E}
$$

Table 1 presents the descriptive statistics of the variables discussed above. It shows, for each variable, the mean, max, min and standard deviation statistics.

\section{The Model}

To examine the effect of the interaction between market power and income diversification on bank stability, we use an econometric model based on a vast theoretical and empirical literature liket the work of Nguyen et al. (2012), Amidu and Wolfe (2013), Soedarmono et al. (2011; 2013), Chien-Chiang et al. (2014) and Meslier et al. (2014):

$$
\begin{aligned}
& \operatorname{STAB}_{i, t}=\alpha_{1} \text { LERNER }_{i, t}+\alpha_{2} \operatorname{Div}_{i, t}+ \\
& \alpha_{3} \text { LERNER }_{i, t} * \operatorname{Div}_{i, t}+\alpha_{4} T C P I B_{i, t}+ \\
& \alpha_{5} I N F_{i, t}+\alpha_{6} L D R_{i, t}+\alpha_{7} L L R_{i, t}+ \\
& \alpha_{8} T C P_{i, t}+\alpha_{9} \operatorname{SIZE}_{i, t}+\varepsilon_{i, t}
\end{aligned}
$$

With $\mathrm{i}$ and c represent banks and time.

The dependent variable STAB is financial stability in the region measured by the Z-score. At this level, there are two main regressions; a regression estimated from ROA denoted by Z-score ROA and a robustness regression estimated from ROE denoted by Z-score ROE. Furthermore, the independent variable LERNER presents a measure of market power degree for the sample banks, Div is the proxy for income diversification and other independent variables are control variables.

The used method is the generalized least squares (GLS) with random effects and fixed-effects in which we use a fixed individual effects model where observed individuals have well-defined and precise characteristics that do not vary in time and which are otherwise independent and uncorrelated. Furthermore, the GLS estimator is more efficient than the Two-stage least squares method (2 SLS) since it takes into account the problem of heteroscedasticity and is solid at the distribution of errors (Fiordelisi et al., 2011).

\section{The Empirical Results}

\section{Results of Estimating the Key Variables and Interpretations}

All the results for the Lerner index for all sample banks show that most banks have low Lerner index values, which is automatically associated with a low degree of market power. Then, we may conclude that we are in a competitive banking market with a low degree of market power. Compared to financial stability of the
MENA region banks, as measured by the Z-score index, the results report low Z-ROA and Z-ROE values. This shows that banks in the MENA region are poorly stable and exposed to banking risks. If the $\mathrm{Z}$-score index decreases, the risk that banks may suffer is high and financial and banking stability deteriorates. Therefore, values of diversification typically range between zero and 0.75. A value of zero means that the bank specializes in a single business, while the value of 0.75 means that the bank generates an income totally balanced on all activities. Estimates obtained on our sample vary between 0 and 0.5 , which allows us to conclude that most MENA region banks diversify in a relatively moderate way their sectors. Then, as a first conclusion we can say that banks in our sample operate in a competitive market with a moderate income diversification, yet they suffer from financial instability.

The results of the main regression and robustness regression are presented in Tables 2 to 4 respectively show the three estimation methods; OLS, GLS fixed effects and GLS random effects. Interpretations of the main regression are based on Table 4 while interpretations of the robustness regression results are based on Table 2 .

The results of the main regression under Z-score ROA show that there is a significant and negative relationship between competition in the MENA banking market and the instability of the system. This implies that if competition increases, volatility decreases, which favors the "Competition-stability" hypothesis. Furthermore, the results indicate that income diversification has no direct effect on the instability of the MENA region banks since there is a positive relationship but not significant between income diversification and financial volatility. As for the interaction variable, we note that interaction between low banking market power and moderate income diversification in the region positively affects financial instability since there is a positive and a significant relationship between market power, diversification and financial volatility. Economically-speaking, this means that in a competitive environment, an income diversification strategy may lead to financial instability. Under competitive pressure, banks may engage in new high-risk activities to gain market share. In this case, financial instability of the sector may be instead the result of a fierce competition between banks born from the desire to distinguish themselves by various nontraditional products, for which banks lack the experience to control its risks. Finally, regarding banksspecific control variables we found that the loan deposit ratio $\mathrm{LDR}$, loan growth rate and bank size affect banking stability and that there is a positive and a significant relationship between these three variables and financial instability, which suggests that increase in loans and bank size is a catalyst to financial instability.

The results of the robustness regression under $\mathrm{Z}$ score ROE, reported in Table 2, are interpreted in the same way as those of the primary regression and we may conclude that the key variable which captures interaction 
between market power and income diversification, "Div. * Lerner", shows that MENA region low-market-power banks are less robust and more unstable when they poorly diversify their income activities.

\section{Conclusion}

The review of the literature pointed out that the relationship between market power and financial stability remains ambiguous. Theoretically, this relationship is summed up by two basic assumptions; one is the "competition -stability" hypothesis and the other is the "competition-fragility" hypothesis. Our goal is to study the validity of these hypotheses through the channel of income diversification by examining the effect of the interaction between market power and diversification on the financial stability of a sample of 157 banks in the MENA region. These are Algeria (10), Bahrain (9), Egypt (23), Iran (8) Iraq (1), Israel (6), Jordan (10), Kuwait (5) Lebanon (18) Libya (4), Morocco (9), Oman (5), Qatar (6), Saudi Arabia (9), Syria (1), Tunisia (14), United Arab Emirates (15) Yemen (4), over a period of 14 years from 2000 to 2013.

To analyze the impact of market power on financial stability, we used two models; a main regression using ROA and a robustness regression using ROE. We consider the Z-score index as an indicator of financial stability where a high value indicates better health. We also used the Lerner index as a measure of market power degree where a high Lerner index implies a monopoly power and a low Lerner index implies a high market competition. The third variable of interest is the Div variable, which is the proxy for income diversification as measured by the Herfindahl-Hirschman
Index (HHI) for each bank taking into account diversification between the core activities.

In reality, the results of these three variables indicate that the banks in our sample operate in a competitive market with a moderate or low income diversification and they suffer from financial instability.

In addition, the results of the main regression and the robustness regression reported in Tables 2 to 4 present the three estimation methods, OLS, GLS with fixed effects and GLS with random effects. Interpretations of the main regression results are based on Table 4 while interpretations of the robustness regression results are based on Table 2 . The results indicate that there is a significant negative relationship between competition in the MENA banking market and instability of its system. This implies that if competition increases, volatility decreases, which favors the "Competition- stability" hypothesis. Moreover, the positive and significant relationship between the interaction variable on the one hand (market power and diversification) and financial instability on the other shows that low-marketpower banks in the MENA region are less robust and more unstable when they poorly diversify their income activities. Economically-speaking, this means that in a competitive environment, an income diversification strategy may lead to financial instability. Under competitive pressure, banks may engage in new high-risk activities to gain market share. In this case, financial instability of the sector may be instead the product of a fierce competition between banks born from the desire to distinguish themselves by various non-traditional activities, for which banks lack the experience to control its risks.

Table 1. Descriptive statistics of the variables of the mode

\begin{tabular}{|c|c|c|c|c|}
\hline Variables & Mean & Max & Min & SD \\
\hline \multicolumn{5}{|l|}{ Market structure } \\
\hline *Lerner index & -17.106 & 4023.00 & -1115.180 & 200.180 \\
\hline \multicolumn{5}{|l|}{ Banking stability } \\
\hline *Zscore-ROA & 4.680 & 47.69 & -12.210 & 4.680 \\
\hline$*$ Zscore-ROE & 0.799 & 9.42 & -7.710 & 1.077 \\
\hline \multicolumn{5}{|l|}{ Income diversification } \\
\hline *Div & 0.330 & 0.65 & -0.410 & 0.158 \\
\hline \multicolumn{5}{|c|}{ Bank-specific control variables } \\
\hline${ }^{*}$ credit risk LLR & 7.170 & 54.37 & 0.000 & 8.170 \\
\hline *banking liquidity LDR & 0.720 & 16.66 & 0.043 & 0.880 \\
\hline *size & 6.790 & 7.05 & 5.830 & 0.250 \\
\hline *loans growth rate & 0.267 & 15.01 & -0.620 & 0.570 \\
\hline \multicolumn{5}{|c|}{ Macroeconomic indicators } \\
\hline *Inflation & 4.470 & 20.60 & -4.900 & 4.620 \\
\hline *GDP growth rate & 5.340 & 20.80 & -62.100 & 4.520 \\
\hline
\end{tabular}

Notes: Calculation of Bankscope, the World Bank and the authors. The data include 157 banks across 18 countries between 2000 and 2013. $Z_{R O A}$ and $Z_{R O E}$ respectively have the $Z$-score index that measures financial stability of banks based respectively on "return on assets" and "return on equity". Lerner index measures the degree of competition in the market, Div. is the proxy for income diversification, TCPIB is GDP growth rate, INF is inflation rate, LDR is the total loans/total deposits ratio, LLR is the ratio of loan loss reserves to total loan, TCP is loan growth rate measured in $\%$ and Size is the logarithmic total average assets 
Table 2. The relationship between market power, diversification and financial stability: The OLS Method

\begin{tabular}{lcrrr}
\hline Variables & Z-score ROA & Z-score ROE & -1.890 \\
\hline Lerner & -0.00090 & -1.030 & $(-0.0047)^{* *}$ & 1.410 \\
Div. & $(5.68)^{*}$ & 7.860 & 0.2900 & 0.073 \\
Div. ${ }^{*}$ Lerner & 0.00323 & 1.210 & $(0.0013)^{* * *}$ & -2.050 \\
LLR & $(0.06)^{*}$ & 4.270 & $(-0.008)^{* *}$ & 1.450 \\
LDR & $(3.102)^{*}$ & 24.800 & 0.054 & -0.670 \\
TCP & $(1.06)^{*}$ & 5.320 & -0.039 & 8.150 \\
Size & $(5.98)^{*}$ & 12.570 & $(1.12)^{*}$ & 3.880 \\
Inflation & -0.017 & -0.690 & $(0.028)^{*}$ & 1.930 \\
TCPIB & $(0.06)^{*}$ & 2.670 & $(0.013)^{* *}$ & 99.000 \\
Obs. & 996.0000 & 996.000 & 0.120 & 0.120 \\
$\mathrm{R}^{2}$ & 0.4460 & 0.446 & 0.120 \\
\hline
\end{tabular}

Note: $Z_{R O A}$ and $Z_{R O E}$ respectively have the Z-score index that measures financial stability of banks based respectively on "return on assets" and "return on equity". The Lerner index measures degree of competition in the market, Div. is the proxy for income diversification, TCPIB is GDP growth rate, INF is inflation rate, LDR is the total loans total/ deposits ratio, LLR is the ratio of loan loss reserves to total loan, TCP is loan growth rate measured in $\%$ and Size is the logarithmic total average assets. This table shows the results of the estimates by General Least Squares (OLS) of the two models (in the sense and meaning of $Z_{R O A}$ and $Z_{R O E}$ ), the first column shows coefficients of variable. Values in parentheses show the t-Student variable. $(* * *),(* *)$ and $(*)$ respectively indicate significance at the $1 \%, 5 \%$ and $10 \%$ thresholds

Table 3. The relationship between market power, diversification and financial stability: The GLS method with fixed effects

\begin{tabular}{lcccr}
\hline Variables & Z-score ROA & \multicolumn{3}{c}{ Z-score ROE } \\
\hline Lerner & $(-0.0012)^{* * *}$ & -1.76 & $(-0.002)$ & -0.71 \\
Div. & $(-0.27)^{* * *}$ & -0.45 & 0.290000 & 1.03 \\
Div. ${ }^{*}$ Lerner & $(0.003)^{* * *}$ & 1.56 & 0.000075 & 0.08 \\
LLR & $(0.89)^{*}$ & 8.59 & 0.062000 & 1.28 \\
LDR & $(-0.79)^{*}$ & -4.11 & $(0.02)^{* *}$ & 2.20 \\
TCP & $(0.68)^{*}$ & 4.36 & -0.012000 & -0.17 \\
Size & 0.605 & 0.96 & $(1.47)^{*}$ & 5.02 \\
Inflation & -0.011 & -0.66 & 0.011000 & 1.38 \\
TCPIB & 0.017 & 1.08 & $(0.02)^{*}$ & 2.76 \\
Obs. & 996.000 & 996.00 & 996.00000 & 0.05000 \\
$\mathrm{R}^{2}$ & 0.130 & 0.13 & 0.000 & 0.05 \\
\hline
\end{tabular}

Note: $Z_{R O A}$ and $Z_{R O E}$ respectively have the Z-score index that measures financial stability of banks based respectively on "return on assets" and "return on equity". The Lerner index measures degree of competition in the market, Div. is the proxy for income diversification, TCPIB is GDP growth rate, INF is inflation rate, LDR is the total loans/total deposits ratio, LLR is the ratio of loan loss reserves to total loan, TCP is loan growth rate measured in \% and Size is the logarithmic total average assets. This table shows the results of the estimates by General Least Squares (GLS) with Fixed Effects of the two models (in the sense and meaning of $Z_{R O A}$ and $\left.Z_{R O E}\right)$, the first column shows coefficients of variables. Values in parentheses show the t-Student variable. $(* * *),(* *)$ and $(*)$ respectively indicate significance at the 1,5 and $10 \%$ thresholds

Table 4. The relationship between market power, diversification and financial stability: The GLS method with random effects

\begin{tabular}{lcrrr}
\hline Variables & \multicolumn{3}{c}{ Z-score ROA } & \multicolumn{2}{c}{ Z-score ROE } \\
\hline Lerner & $(-0.0012)^{* * *}$ & -1.88 & -0.0030 & -1.39 \\
Div. & 0.52 & 0.85 & 0.2650 & 1.13 \\
Div.*Lerner & $(0.003)^{* * *}$ & 1.82 & 0.0006 & 0.90 \\
LLR & $(1.13)^{*}$ & 10.73 & 0.0590 & 1.45 \\
LDR & $(-0.42)^{* *}$ & -2.47 & 0.0020 & -0.49 \\
TCP & $(0.73)^{*}$ & 4.73 & -0.0200 & -0.51 \\
Size & $(2.01)^{*}$ & 3.68 & $(1.103)^{*}$ & 6.56 \\
Inflation & -0.016 & -0.91 & $(0.019)^{*}$ & 2.58 \\
TCPIB & 0.024 & 1.51 & $(0.016)^{*}$ & 2.36 \\
Obs. & 996.00 & 996.00 & 996.000 & 996.00 \\
R $^{2}$ & 0.41 & 0.41 & 0.220 & 0.22 \\
t-Hausman & - & - & 26.410 & 26.41 \\
\hline
\end{tabular}

Note: $Z_{R O A}$ and $Z_{R O E}$ respectively have the Z-score index that measures financial stability of banks based respectively on "return on assets" and "return on equity". The Lerner index measures degree of competition in the market, Div. is the proxy for income diversification, TCPIB is GDP growth rate, INF is inflation rate, LDR is the total loans/total deposits ratio, LLR is the ratio of loan loss reserves to total loan, TCP is loan growth rate measured in \% and Size is the logarithmic total average assets. This table shows the results of the estimates by General Least Squares (GLS) with Random Effects of the two models (in the sense and meaning of $Z_{R O A}$ and $\left.Z_{R O E}\right)$, the first column shows coefficients of variables. Values in parentheses show the t-Student variable. $\left({ }^{* * *}\right),\left({ }^{* *}\right)$ and $(*)$ respectively indicate significance at the 1,5 and $10 \%$ thresholds 


\section{Author's Contributions}

Sami Mensi and Widede Labidi equally contributed in this work.

\section{Ethics}

This article is original and contains unpublished material. The corresponding author confirms that both the authors have read and approved the manuscript and no ethical issues involved.

\section{References}

Agoraki, M.E.K.., M.D. Delis and F. Pasiouras, 2011. Regulations, competition and bank risk-taking in transition countries. J. Financ. Stability, 7: 38-48. DOI: $10.1016 /$ j.jfs.2009.08.002

Amidu, M. and S. Wolfe, 2013. Does bank competition and diversification lead to greater stability? Evidence from emerging markets. Rev. Develop. Finance, 3: 152-166. DOI: $10.1016 /$ j.rdf.2013.08.002

Ariss, R.T., 2010. On the implications of market power in banking: Evidence from developing countries. J. Bank. Finance, 34: 765-775. DOI: $10.1016 /$ j.jbankfin.2009.09.004

Baele, L., O. De Jonghe and V.R. Vennet, 2007. Does the stock market value bank diversification? J. Banking Finance, 31: 1999-2023.

Beck, T., A. Demirguc-Kunt and R. Levine, 2006. Bank concentration, competition and crises: First results. J. Bank. Finance, 30: 1581-1603. DOI: $10.1016 /$ j.jbankfin.2005.05.010

Berger, A.N., L.F. Klapper and R.T. Ariss, 2009. Bank competition and financial stability. J. Financ. Services Res., 35: 99-118. DOI: $10.1007 / \mathrm{s} 10693-008-0050-7$

Boyd, J.H., G. De Nicolo and A.M. Jalal, 2006. Bank risktaking and competition revisited: New theory and new evidence. IMF Working Paper, Research Department, International Monetary Fund.

Bresnahan, T.F., 1982. The oligopoly solution concept is identified. Economic Lett., 10: 87-92.

Carba-Valverde, S. and R. Fernandez, 2007. The determinants of bank margins in European banking. J. Bank. Finance, 31: 2043-2063.

Cihak, M. and K. Schaeck, 2007. Banking competition and capital ratios. IMF Working Papers 07/216, International Monetary Fund.

Claessens, S. and L. Laeven, 2004. What drives bank competition? Some international evidence. J. Money, Credit Banking, 36: 563-583.
Chien-Chiang, L., M.F. Hsieh and S.J. Yang, 2014. The relationship between revenue diversification and bank performance: Do financial structures and financial reforms matter? Japan World Econ., 29: 18-35. DOI: 10.1016/j.japwor.2013.11.00

Chiorazzo, V., C. Milani and F. Salvini, 2008. Income diversification and bank performance: Evidence from Italian banks. J. Financ. Services Res., 33: 181-203.

Delis, M.D., and M. Tsionas, 2009. The joint estimation of bank-level market power and efficiency. J. Bank. Finance, 33: 1842-1850.

De Guevara, J.F. and J. Maudos, 2004. Measuring welfare loss of market power: An application to European banks. Applied Economics Lett., 11: 833-836.

De Guevara, J.F., J. Maudos and F. Perez, 2005. Market power in European banking sectors. J. Financ. Services Res., 27: 109-138. DOI: $10.1007 / \mathrm{s} 10693-005-6665-\mathrm{z}$

De Jonghe, O., 2010. Back to the basics in banking? A micro-analysis of banking system stability. J. Financ. Intermediation, 19: 387-417.

DeYoung, R. and P.R. Karin, 2001. Product mix and earnings volatility at commercial banks: Evidence from a degree of total leverage model. J. Financ. Intermediation, 10: 54-84.

DeYoung, R. and T. Rice, 2004. How do banks make money? The Fallacies of Fee Income, Economics Perspectives.

DeYoung, R. and G. Torna, 2013. Nontraditional banking activities and bank failures during the financial crisis. J. Financ. Intermediation, 22: 397-421.

Fiordelisi, F., D. Marques-Ibanez and P. Molyneux, 2011. Efficiency and risk in European banking. J. Bank. Finance, 35: 1315-1326.

Fonseca, A.R. and F. González, 2010. How bank capital vary across countries: The influence of cost of deposits, market power and bank regulation. J. Bank. Finance, 34: 892-902.

Froot, K.A. and J.C. Stein, 1998. Risk management, capital budgeting and capital structure policy for financial institutions: An integrated approach. J. Financ. Econo., 47: 55-82.

Goddard, J.A. and J.O.S. Wilson, 2006. Measuring competition in banking: A disequilibrium approach. EIEF Working Papers $\mathrm{N}^{\circ}$ 0808, University of Wales, Bangor.

Hirtle, B.J. and K.J. Stiroh, 2007. The return to retail and the performance of US banks. J. Banking Finance, 31: 1101-1133.

Jimnez, G. and J. Saurina, 2004. Collateral, type of lender and relationship banking as determinants of credit risk. J. Bank. Finance, 28: 2191-2212. 
Landskroner, Y., D. Ruthenberg and D. Zaken, 2005. Diversification and performance in banking: The Israeli case. J. Financ. Services Res., 27: 27-49.

Lau, L.J., 1982. On identifying the degree of competitiveness from industry price and output data. Econ. Lett., 10: 93-99.

Lepetit, L., E. Nys, P. Rous and A. Tarazi, 2008. Bank income structure and risk: An empirical analysis of European banks. J. Bank. Finance, 32: 1452-1467. DOI: 10.1016/j.jbankfin.2007.12.002

Lozano-Vivas, A. and F. Pasiouras, 2010. The impact of non-traditional activities on the estimation of bank efficiency: International evidence. J. Bank. Finance, 34: 1436-1449.

Maudos, J. and J.F. De Guevara, 2004. Factors explaining the interest margin in the banking sectors of the European Union. J. Bank. Finance, 28: 2259-2281.

Maudos, J. and J.F. De Guevara, 2007. The cost of market power in the European banking sectors: Social welfare loss vs. inefficiency cost. J. Bank. Finance, 31: 2103-2125.

Meslier, C., R. Tacneng and A. Tarazi, 2014. Is bank income diversification beneficial? Evidence from an emerging economy. J. Int. Financ. Markets Institutions Money, 31: 97-126. DOI: $10.1016 /$ j.intfin.2014.03.007

Mercieca, S., K. Schaeck and S. Wolfe, 2007. Small European banks: Benefits from diversification? J. Bank. Finance, 31: 1975-1998. DOI: 10.1016/j.jbankfin.2007.01.004

Mishkin, F.S., 2006. How big a problem is too big to fail? J. Econ. Literature, 44: 988-1004.

Nguyen, M., M. Skully and S. Perera, 2012. Market power, revenue diversification and bank stability: Evidence from selected South Asian countries. J. Int. Financ. Markets, Institutions Money, 22: 897-912. DOI: 10.1016/j.intfin.2012.05.008

Panzar, J.C. and J.N. Rosse, 1987. Testing for 'mon opoly' equilibrium. J. Industrial Econ., 35: 443-456.

Sallami, S. and M.A. Chaffai, 2011. Banking competition and efficiency: The case of the Tunisian commercial banks. ERF Working Papers $\mathrm{N}^{\circ}$ ERF18th MIC06
Sanya, S. and S. Wolfe, 2011. Can banks in Emerging countries benefit from revenue diversification? J. Financ. Services Res., 40: 79-101.

Schaeck, K., M. Cihak and S. Wolfe, 2009. Are competitive banking systems more stable? J. Money, Credit Bank, 41: 711-734. DOI: $10.1111 /$ j.1538-4616.2009.00228.x

Stiroh, K.J. and J. Kevin, 2004. Diversification in banking: Is noninterest income the answer? J. Money, Credit Banking, Blackwell Publishing, 36: 853-82.

Stiroh, K.J., 2004a. Do community banks benefit from diversification. J. Financ. Services Res., 25: 135-160.

Stiroh, K.J., 2004b. Diversification in banking: Is noninterest income the answer? J. Money, Credit Banking, 36: 853-882.

Stiroh, K.J., 2005. A portfolio view of banking with interest and noninterest assets. Federal Reserve Bank of New York, Mimeo.

Stiroh, K.J., 2006. New evidence on the determinants of bank risk. J. Financ. Service Res., 30: 237-263.

Stiroh, K.J. and A. Rumble, 2006. The dark side of diversification: The case of U.S. financial holding companies. J. Banking Finance, 30: 2131-2161.

Soedarmono, W., F. Machrouh and A. Tarazi, 2011. Bank market power, economic growth and financial stability: Evidence from Asian banks. J. Asian Econ., 22: 460-470. DOI: $10.1016 /$ j.asieco.2011.08.003

Soedarmono, W., F. Machrouh and A. Tarazi, 2013. Bank competition, crisis and risk taking: Evidence from emerging markets in Asia. J. Int. Financ. Markets Institutions Money, 23: 196-221. DOI: 10.1016/j.intfin.2012.09.009

Trujillo-Ponce, A., 2013. What determines the profitability of banks? Evidence from Spain. Accounting Finance, 53: 561-586.

Uhde, A. and U. Heimeshoff, 2009. Consolidation in banking and financial stability in Europe: Empirical evidence. J. Bank. Finance, 33: 299-1311. DOI: $10.1016 /$ j.jbankfin.2009.01.006 